\title{
CERMET COATINGS \\ OF CHROMIUM CARBIDE-NICHROME SYSTEM PRODUCED BY SUPERSONIC PLASMA GAS AIR SPRAYING
}

\author{
V.N. KORZHIK, A.L. BORISOVA, V.V. POPOV, M.V. KOLOMYTSEV, A.A. CHAJKA, \\ V.I. TKACHUK and N.V. VIGILYANSKAYA \\ E.O. Paton Electric Welding Institute, NASU \\ 11 Bozhenko Str., 03680, Kiev, Ukraine. E-mail: office@paton.kiev.ua
}

\begin{abstract}
It is a well-known fact that application of supersonic methods of thermal spray deposition results in significant increase of service properties of parts. However, up to moment no trails were made on producing of carbide or cermet coatings with the help of supersonic methods of plasma spraying. Present work is dedicated to production of cermet coatings from chromium carbide-nichrome compositions using a method of supersonic plasma gas air spraying (SPGAS). SPGAS technology has series of advantages in comparison with well-known technology of HVOF spraying. First of all, it concerns efficiency, economy and characteristics (temperature, speed) of gas jet. Structure and phase composition of produced coatings were investigated. It is shown that spraying using supersonic gas jets promotes for increase of content of $\mathrm{Cr}_{7} \mathrm{C}_{3}$ carbide and reduction of $\mathrm{NiCr}$ in the coatings as a result of oxidation and formation of oxides. Coating from composite powder differs by higher level of density and homogeneity, has layered fine-laminated structure with inclusions of fine carbides, contains lower amount of oxide phase, but larger quantity of chromium carbide $\mathrm{Cr}_{3} \mathrm{C}_{2}$ in comparison with coating from mechanical mixture $\mathrm{Cr}_{3} \mathrm{C}_{2}+\mathrm{NiCr}$. These coatings can be recommended for application as wear-resistant at increased temperatures. 6 Ref., 6 Tables, 7 Figures.
\end{abstract}

K e y words: supersonic plasma gas air spraying, cermet coatings, chromium carbide, powders, microstructure, phase composition, microhardness

Plasma coatings based on chromium carbides are characterized by combination of such properties as resistance to wear by abrasive particles and hard surfaces at high temperatures $\left(540-840{ }^{\circ} \mathrm{C}\right)$, high resistance under conditions of fretting-corrosion and aggressive media (for example, in liquid sodium at $200-625{ }^{\circ} \mathrm{C}$ ), heat resistance at temperatures to $980{ }^{\circ} \mathrm{C}$, radiation resistance [1].

$\mathrm{Cr}_{3} \mathrm{C}_{2}$ mechanical mixtures (rarely its mixture with $\mathrm{Cr}_{7} \mathrm{C}_{3}$ or $\mathrm{Cr}_{23} \mathrm{C}_{6}$ carbide) with such metals as $\mathrm{Ni}, \mathrm{Co}, \mathrm{Ni}+\mathrm{Cr}, \mathrm{NiCr}$ at different combination of component content (amount of metallic binder can be from 6-8 to $45 \mathrm{wt} . \%$ ) are used for spray deposition of cermet coatings with chromium carbide.
Main methods, which are used for spray deposition of coatings with chromium carbides, are plasma, detonation and HVOF spraying [1-3].

It is a well known fact that application of supersonic methods of thermal coating deposition results in significant increase of their service properties. However, up to moment no trails were made on producing of carbide or cermet coatings with the help of supersonic methods of plasma spraying.

Present work is dedicated to production of cermet coatings from chromium carbide-nichrome compositions using a method of supersonic plasma gas air spraying (SPGAS), examination of structure and phase composition of produced coatings.

SPGAS technology has series of advantages in comparison with well-known technology of

Table 1. Comparative characteristics of HVOF and SPGAS technologies

\begin{tabular}{||c|c|c|c|c|c|c|c|c|c||}
\hline \multirow{2}{*}{ Technology } & \multicolumn{4}{|c|}{ Gas consumption, $\mathrm{m}^{3} / \mathrm{h}$} & \multicolumn{2}{c|}{ Powder consumption, $\mathrm{kg} / \mathrm{h}$} & \multirow{2}{*}{$\begin{array}{c}\text { Coefficient } \\
\text { of material } \\
\text { use, } \%\end{array}$} & \multicolumn{2}{|c|}{ Jet characteristics } \\
\cline { 2 - 11 } & Propane & $\mathrm{O}_{2}$ & $\mathrm{~N}_{2}$ & Air & $\begin{array}{c}\text { Metallic } \\
\text { alloys }\end{array}$ & Oxides & $\mathrm{m} / \mathrm{s}$ & $\begin{array}{c}\text { Temperature, } \\
{ }^{\circ} \mathrm{C}\end{array}$ \\
\hline HVOF & $3-4$ & $15-21$ & 1 & - & Up to 23 & - & $40-75$ & $1400-2700$ & 2800 \\
\hline SPGAS & $0.3-40$ & - & - & $10-40$ & Up to 50 & Up to 20 & $60-80$ & 3000 & $3200-6300$ \\
\hline
\end{tabular}


SCIENTIFIC AND TECHNICAL

Table 2. Composition of powders

\begin{tabular}{||c|c|c|c|c|c|c|c||}
\hline \hline \multirow{2}{*}{ Powder grade } & \multicolumn{9}{|c|}{ Content of elements, wt.\% } & Si & Rest \\
\cline { 2 - 8 } & $\mathrm{Cr}$ & $\mathrm{Ni}$ & $\mathrm{C}$ & $\mathrm{Mn}$ & $\mathrm{Fe}$ & 0.065 & 0.41 \\
\hline PP-53 & 71.10 & 17.10 & 9.49 & 0.036 & 1.75 & \multicolumn{4}{|c||}{ Not indicated } \\
\hline PP-53B & Base & 20 & 9.40 & \multicolumn{5}{|c|}{} \\
\hline
\end{tabular}

Table 3. Composition of particles of initial powders based on XSMA results

\begin{tabular}{||l|c|c|c|c|c||}
\hline \multirow{2}{*}{\multicolumn{1}{c|}{ Powder particle }} & \multicolumn{5}{c||}{ Content of elements, wt.\% } \\
\cline { 2 - 6 } & $\mathrm{Cr}$ & $\mathrm{Ni}$ & $\mathrm{C}$ & $\mathrm{O}^{*}$ & Additives \\
\hline Carbide (1 in Figure 1, $a, c)$ & $70.10-79.70$ & $1.50-5.60$ & $18.9-21$ & - & $\mathrm{Fe}-0.73$ \\
\hline Metallic (2 in Figure 1, $a, c)$ & $52-71.10$ & $24.23-24.39$ & - & - & $\mathrm{W}-0.71 ; \mathrm{Fe}-1.45$ \\
\hline Cermet (3 in Figure 1, $b, d)$ & $30.77-68.10$ & $10.55-49.81$ & $9.17-13.60$ & $6.2-7.7$ & $\mathrm{Mg}-\begin{array}{c}0.48-1.24 ; \mathrm{Al}-0.6 ; \mathrm{Fe}-0.55 ; \\
\mathrm{W}-1.13-1.45\end{array}$ \\
\hline
\end{tabular}

HVOF spraying. First of all, it concerns efficiency, economy (cost of gases) and characteristics of gas jet (temperature, speed) (Table 1).

Coating spray deposition in present work was carried out on «Kiev-S» installation, developed by Gas Institute and PWI of the NAS of Ukraine. Air mixture with addition of propane (around 4 vol.\%) was used as plasma gas at following technological parameters: $I=260 \mathrm{~A}, U=360 \mathrm{~V}$,
$180 \mathrm{~mm}$ distance, air pressure made $4 \mathrm{~atm}$ and consumption $20 \mathrm{~m}^{3} / \mathrm{h}$.

Powders of two types, namely PP-53 $\mathrm{Cr}_{3} \mathrm{C}_{2} 25(\mathrm{Ni} 20 \mathrm{Cr})$ and $\mathrm{PP}-53 \mathrm{~B} \mathrm{Cr}_{3} \mathrm{C}_{2}(\mathrm{Ni} 20 \mathrm{Cr})$ (Table 2) from «Bay State Surface Technologies, Inc.» (USA) were used as materials for coating spray deposition.

Powders of particle size 15-44 $\mu \mathrm{m}$ were applied for coating spray deposition.
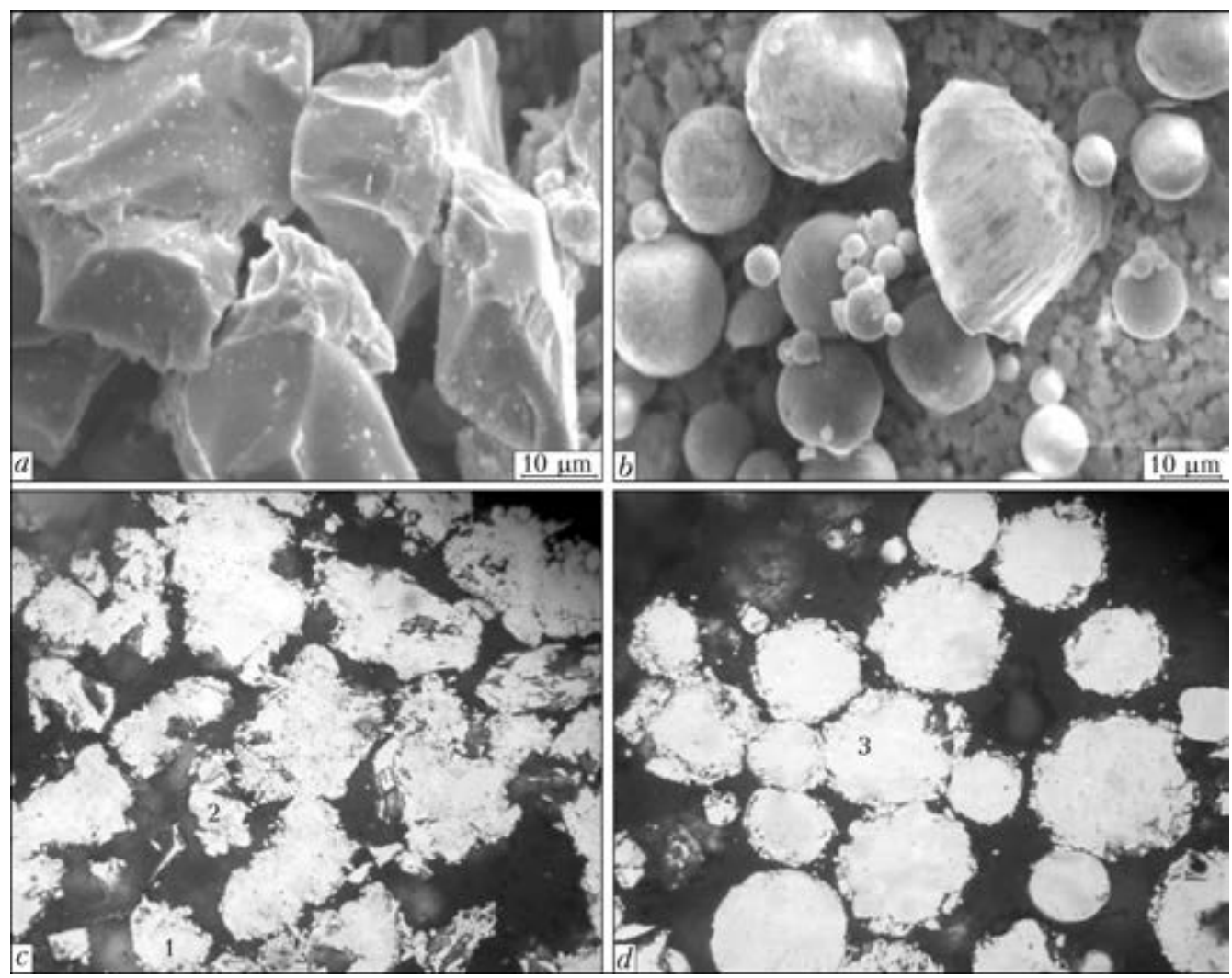

Figure 1. Appearance $(a, c)$ and microstructure $(\times 800)$ of particles $(b, d)$ of PP-53 $(a, c)$ and PP-53B $(b, d)$ powders: 1 - carbide; 2 - metallic; 3 - cermet particles 

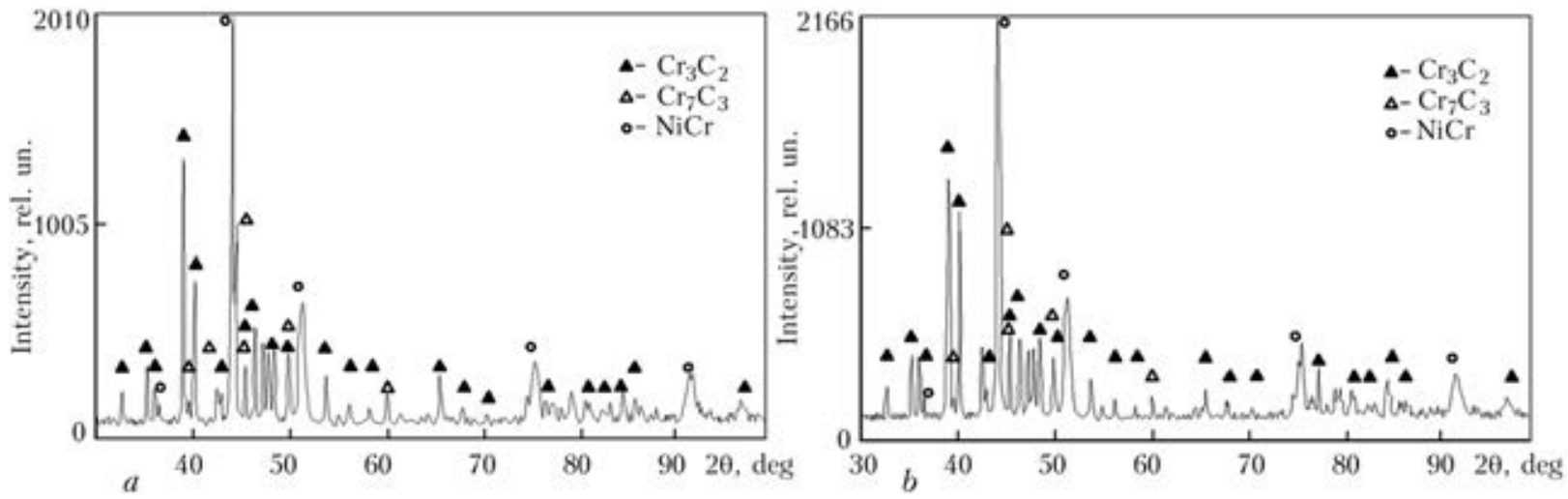

Figure 2. X-ray patterns of particles of $\mathrm{Cr}_{3} \mathrm{C}_{2}+\mathrm{NiCr}$ powder: $a-\mathrm{PP}-53 ; b-\mathrm{PP}-53 \mathrm{~B}$

Examinations of initial powders showed that they differ by appearance, microstructure, microhardness and phase composition. Thus, PP-53 powder consists of faceted particles (Figure $1 a$, $c$ ) and being a mechanical mixture of carbide and metallic particles, which vary vastly on microhardness $(13300 \pm 1500$ and $1980 \pm 600 \mathrm{MPa}$, respectively).
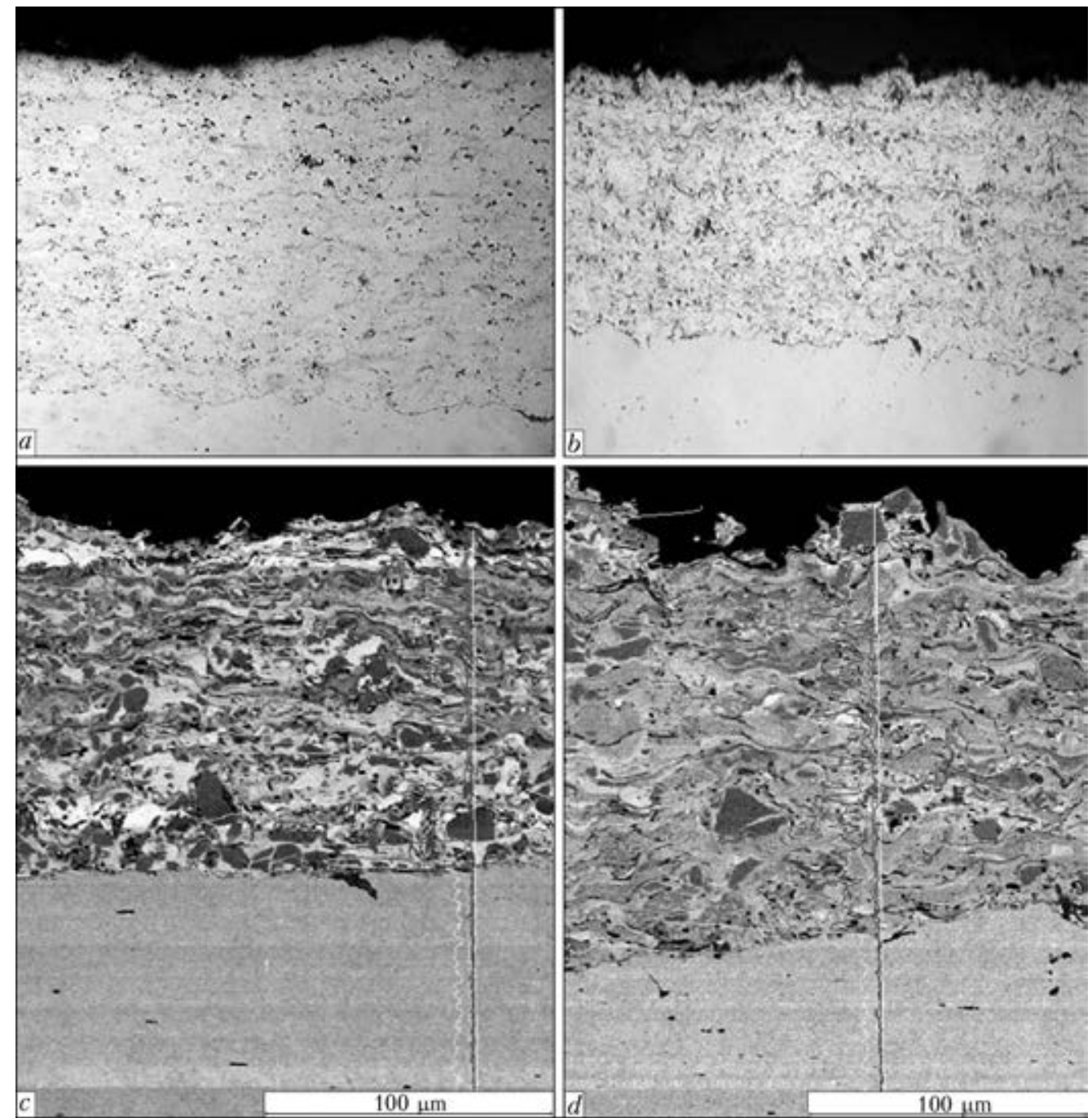

Figure 3. Microstructure of coatings from PP-53 $(a, c)$ and PP-53B $(b, d)$ powder $(a, b-$ Neophot microscope, $\times 400$; $c, d-$ CamScan electron-probe analysis) 
SCIENTIFIC AND TECHNICAL

Table 4. Characteristic of sprayed coatings

\begin{tabular}{|c|c|c|c|}
\hline \multirow{2}{*}{ Powder grade } & \multicolumn{2}{|c|}{ Microhardness, MPa } & \multicolumn{2}{c}{ Phase composition, wt.\% } \\
\cline { 2 - 3 } & Average & Most probable & \\
\hline PP-53 & $8420 \pm 1550$ & $9000 ; 11500$ & $\mathrm{Cr}_{7} \mathrm{C}_{3}-26 ; \mathrm{Cr}_{3} \mathrm{C}_{2}-11 ; \mathrm{NiCr}^{2}-48 ; \mathrm{NiCr} \mathrm{O}_{4}-15$ \\
\hline PP-53B & $9960 \pm 1400$ & 10500 & $\mathrm{Cr}_{7} \mathrm{C}_{3}-21 ; \mathrm{Cr}_{3} \mathrm{C}_{2}-15 ; \mathrm{NiCr}-53 ; \mathrm{NiCrO}-11$ \\
\hline
\end{tabular}
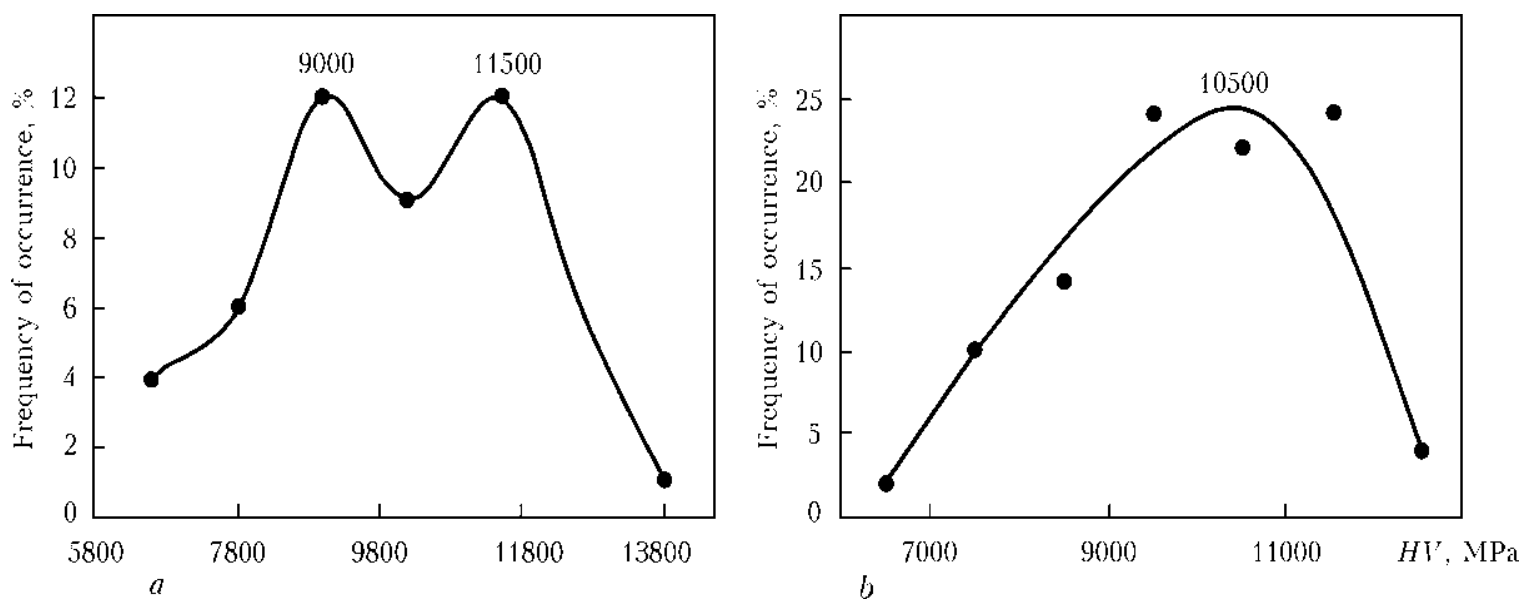

Figure 4. Microhardness variation curves of plasma coatings from PP-53 $(a)$ and PP-53B (b) powders

carbon amount in the carbide particles (1921 wt.\%), they are close to $\mathrm{Cr}_{3} \mathrm{C}_{2}$ (19.34 vol. \%) carbide on composition. Moreover, $\mathrm{Cr}_{7} \mathrm{C}_{3}$ carbide (9.01 wt.\% C) (Figure 2, $a$ ) was found in powder using X-ray phase structural analysis (XPSA) method.

Particles of PP-53B powder contain all three elements $(\mathrm{Cr}, \mathrm{Ni}$ and $\mathrm{C}$ ) as well as additives of these elements such as small amount of $\mathrm{Mg}, \mathrm{Al}$,
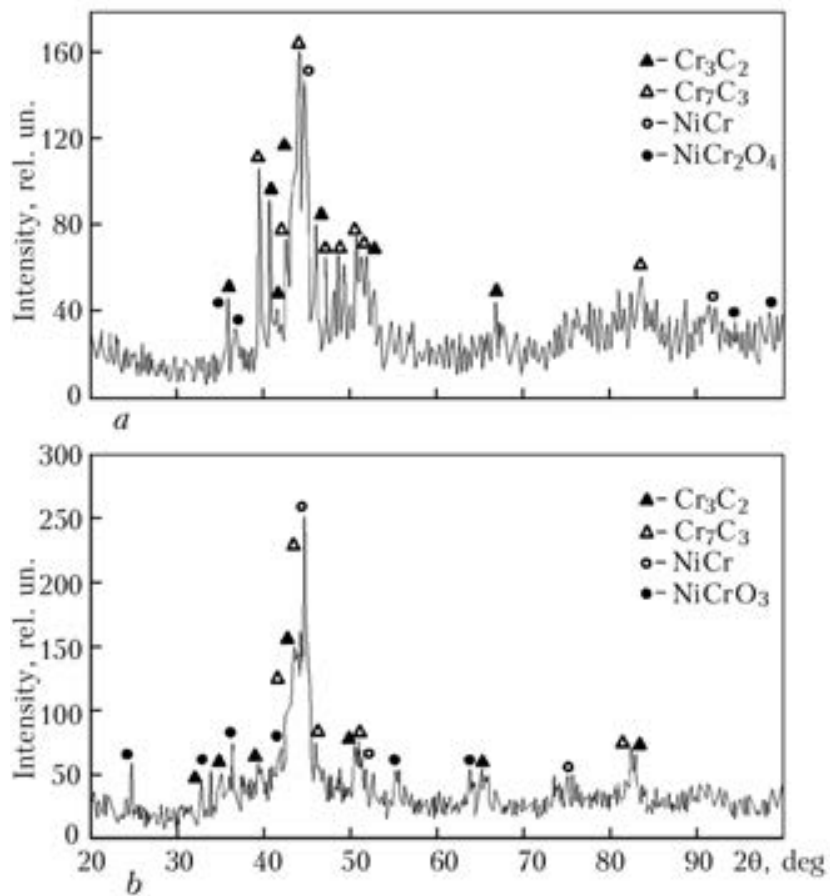

Figure 5. X-ray patterns of sprayed coatings: $a-$ PP-53; $b$ - PP-53B powder
W, Fe and Ca (see Table 3). Some particles have areas enriched by oxygen at the level of 6-7 wt.\%.

At the same time, results of XPSA of PP-53B particles indicate that they do not differ from PP-53 powder (Figure 2, b) on qualitative content, and since each particle contains metallic as well as carbide phases, the powder can be considered as composite one, consisting from cermet particles.

Metallographic examination of sprayed coatings determined no fundamental differences in their structure depending on powder type ( $\mathrm{Fi}^{-}$ gure 3). The only thing that can be noted is higher level of homogeneity of coatings from composite powder (PP-53B) in comparison with coatings from mechanical mixture (PP-53). Besides, some difference is observed in values of average microhardness of coatings and nature of microhardness variation curves (Table 4, Figure 4).

Thus, two most probable values of microhardness can be marked on microhardness variation curve of the coating, produced from PP-53 powder (mechanical mixture $\mathrm{Cr}_{3} \mathrm{C}_{2}$ and $\mathrm{NiCr}$ ). This can be an evidence of presence in the structure, as in initial powder, of zones with harder carbide phases $(H V=11500 \mathrm{MPa})$ and metal enriched zones $(H V=9000 \mathrm{MPa})$. Microhardness variation curve of the coating from composite powder $\mathrm{PP}-53 \mathrm{~B}$ has only one probable value of microhardness $10500 \mathrm{MPa}$, i.e. average between two indicated above.

XPSA of phase composition of sprayed coatings showed (Figure 5) that they contain chro- 
Table 5. Content of elements, determined by XSMA method, in structural zones of coatings from PP-53 and PP-53B powders (acc. to Figure $6, a$ and $b$, respectively)

\begin{tabular}{|c|c|c|c|c|c|c|}
\hline \multirow{2}{*}{$\begin{array}{l}\text { Spectrum to } \\
\text { be analyzed }\end{array}$} & \multicolumn{5}{|c|}{ Content of elements, wt.\% } & \multirow{2}{*}{ Supposed phase } \\
\hline & $\mathrm{Cr}$ & $\mathrm{Ni}$ & $\mathrm{C}$ & $\mathrm{O}$ & $\mathrm{Fe}$ & \\
\hline $1(a)$ & 13.33 & 81.57 & - & - & 4.30 & $\mathrm{NiCr}$ \\
\hline $2(a)$ & 81.82 & 1.45 & 16.72 & - & - & $\mathrm{Cr}_{7} \mathrm{C}_{3}$ \\
\hline $3(a)$ & 89.40 & - & 10.60 & - & - & $\mathrm{Cr}_{3} \mathrm{C}_{2}$ \\
\hline $4(a)$ & 56.41 & 18.50 & 4.87 & 20.22 & - & Oxide \\
\hline $1(b)$ & 61.13 & 25.89 & 11.66 & - & - & \multirow[t]{3}{*}{ Zones of cermets (metal + carbide $)$} \\
\hline $2(b)$ & 13.99 & 75.11 & 8.71 & - & 0.93 & \\
\hline $3(b)$ & 26.50 & 61.97 & 8.89 & - & 0.79 & \\
\hline $4(b)$ & 28.93 & 59.57 & - & 9.44 & 0.49 & Oxide \\
\hline
\end{tabular}

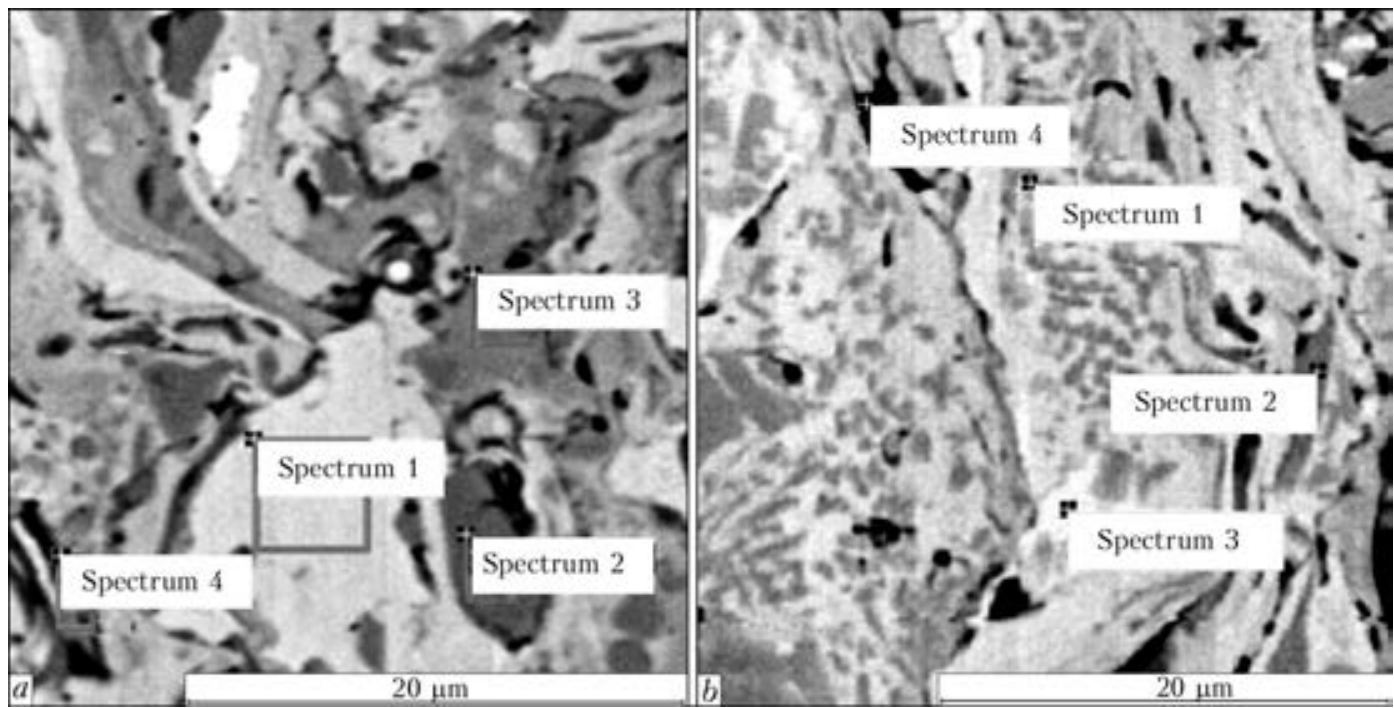

Figure 6. Zones of coatings from PP-53 ( $a$ ) and PP-53B ( $b$ ) powders examined by XSMA method

mium carbide $\mathrm{Cr}_{3} \mathrm{C}_{2}, \mathrm{Cr}_{7} \mathrm{C}_{3}$, nichrome $\left(\mathrm{Ni}_{80} \mathrm{Cr}_{20}\right)$ and oxides $\mathrm{NiCr}_{2} \mathrm{O}_{4}$ (for coating from mechanical mixture) or $\mathrm{NiCrO}_{3}$ (for coating from composite powder), the latter were not found in initial powders. Presence of indicated phased in the sprayed coatings conforms the results of local XSMA ( Table 5) of separate structural elements of the sprayed coatings (Figure 6).

It can be noted when comparing intensity of $\mathrm{X}$-ray reflections of separate phases in initial

Table 6. Results of XSMA of sprayed coating from PP-53B powder (acc. to Figure 7)

\begin{tabular}{|c|c|c|c|c|c|c||}
\hline \multirow{2}{*}{$\begin{array}{c}\text { Spectrum } \\
\text { to be } \\
\text { analyzed }\end{array}$} & \multicolumn{7}{|c||}{ Composition, wt.\% } \\
\cline { 2 - 7 } & $\mathrm{C}$ & $\mathrm{O}$ & $\mathrm{Cr}$ & $\mathrm{Fe}$ & $\mathrm{Ni}$ & $\mathrm{W}$ \\
\hline 2 & 1.91 & - & - & 97.66 & - & - \\
\hline 3 & 9.10 & 6.10 & 52.61 & 2.62 & 29.58 & - \\
\hline 4 & 9.72 & 5.32 & 49.80 & 3.93 & 30.39 & 0.83 \\
\hline 5 & 8.56 & 6.55 & 55.21 & 2.23 & 26.75 & 0.68 \\
\hline 6 & 8.38 & 7.15 & 55.76 & 2.59 & 25.38 & 0.73 \\
\hline
\end{tabular}


ings (Figure 7, Table 6) showed that averaged composition (spectrum 3) and content of separate zones on depth (spectra 4-6) are somewhat differ from values of the initial powder (see Table 1). This takes place as a result of appearance of oxide phases in the coatings. At that, amount of oxygen in the case of PP-53B powder coating somewhat increases in direction from base interface to outer surface of the coating, while carbon content is reduced to the contrary.

The similar dependence is observed for PP-53 powder coating. This fact is related with rise of temperature of coating being sprayed in proportion to build-up of coating layer. Comparison of characteristics of sprayed coatings from PP-53 and PP-53B powders allows for noting that coating from composite powder differs by higher level of density and homogeneity, has layered fine-lamellar structure with inclusions of fine carbides, contains lower amount of oxide phase, but lager quantity of chromium carbide $\mathrm{Cr}_{3} \mathrm{C}_{2}$ in comparison with coating from mechanical mixture $\mathrm{Cr}_{3} \mathrm{C}_{2}+\mathrm{NiCr}$.

It is a well-known fact that refractory properties, stability and hardness of chromium carbides are reduced with decrease of carbon amount in them $[4,5]$. Therefore, carbon loss is undesirable in the processes of thermal spraying of cermet chromium carbide based coatings. Review paper [6] dedicated to effect of thermal spraying methods (HVOF, air plasma spraying (APS), vacuum plasma spraying (VPS) and detonation spraying) on properties of the coatings from mechanical mixture $\mathrm{Cr}_{3} \mathrm{C}_{2}+\mathrm{NiCr}$ indicates that hardness, abrasive wear resistance and thermal resistance of the coatings depend on carbon loss in spraying. Thus, for example, VPS coatings have higher hardness and abrasive wear resistance, but lower thermal resistance among others, and APS coatings with argon-helium plasma gas are superior on their properties to the coatings using argon-hydrogen mixture etc.

The results of present work allows for concluding that quality of $\mathrm{Cr}_{3} \mathrm{C}_{2}+\mathrm{NiCr}$ composition coating can also be increased with the help of composite powder of the same compositions instead of mechanical mixture.

1. Borisov, Yu.S., Kharlamov, Yu.A., Sidorenko, S.L. et al. (1987) Thermal coatings from powder materials: Refer. Book. Kiev: Naukova Dumka.

2. Guilemagy, M., Nutting, I., Llorca-Isern, N. (1996) Microstructural examination of HVOF chromium carbide coatings for high temperature applications. $J$. Thermal Spray Techn., 5(4), 483-489.

3. Guilemagy, J.M., Espallargas, N., Suegama, P.H. et al. (2006) Comparative study of $\mathrm{Cr}_{3} \mathrm{C}_{2}-\mathrm{NiCr}$ coating. Corrosion Sci., 48, 2998-3013.

4. Kiffer, R., Benezovsky, F. (1968) Solid materials. Moscow: Metallurgiya.

5. (1986) Properties, production and application of refractory joints. Ed. by T.Ya. Kosolapova. Moscow: Metallurgiya.

6. Takenchi, J., Nakahira-Kobe, A., Takara, G. (1993) Barbezat-Wohlen Plasma-Technik. $\mathrm{Cr}_{3} \mathrm{C}_{2}+\mathrm{NiCr}$ cermet coatings. In: Proc. of Thermal Spray Conf. (Aachen, 1993), 1-14. 